\title{
TERMINATION OF A FRANCHISING AGREEMENT IN THE LIGHT OF THE POSITIVE LEGISLATION OF THE REPUBLIC OF SERBIA**
}

\begin{abstract}
The needs of capital for new markets through the minimum of investment can be achieved through franchising, as a specific investment method of contracting business. Using the methods of successful operations, reduced investment risks and autonomy in operations are among the decisive reasons for joining the franchise network by the potential franchisee. In line with the absence of legal regulation in the Republic of Serbia, the Law on Contracts and Torts is being applied on a franchise agreement. The provisions of the Law on Contracts and Torts regulating the termination of a contract of commercial agency and the contract on license can be applied to the termination of a franchise agreement in an analogous manner.

Key words: franchising agreement, franchise, franchisor, franchisee, ordinary notice, extraordinary cancellation, serious reasons, Law on Contracts and Torts.
\end{abstract}

\section{Introduction}

Contemporary market movements and the need of capital to conquer new markets through minimum investments undoubtedly significantly affect development of contemporary autonomous business operations of commercial law. One in the series of business operations that are the product of movements on the market of goods and capital is a business franchise and, consequently, the agreement as an instrument of implementation thereof. Franchising is a specific

\footnotetext{
*strahinja.miljkovic@pr.ac.rs

${ }^{* *}$ This paper was presented at the International Scientific Conference "Law in the context of addressing the Challenges of the Contemporary World", held at the Faculty of Law, University of Niš, on $13^{\text {th }}-14^{\text {th }}$ April 2018.
} 
investment method of contractual business operations. The reasons that affect the expansion of business franchises are as follows: a) need for successful business operations growth, and $b$ ) capability to achieve such a growth by liaising with others that own capital and labour force for such a thing (Mendelsohn, 2004:1).

Franchising, enables the receiver of franchise to expand their business with minimum investments and minimum investment risks at the target market. The significance of franchising lies in enabling the franchisee to access a developed franchising network. Having accessed a franchising network, the franchisee uses all the advantages of the developed and tested-in-practice business operations system. ${ }^{1}$

\section{Law on Contracts and Torts (TLC) and Franchising Agreement}

The franchising agreement is characterized by continuous contractual relationship, therefore, the provisions regulating the termination of permanent obligations may be applied to it (Миљковић, 2014:355). In line with the absence of legal regulation in the Republic of Serbia, the Law on Contracts and Torts (hereinafter: LCT) is being applied on a franchise agreement. ${ }^{2}$

The provisions of the Law on Contracts and Torts - LCT regulating the termination of a contract on commercial agency and the contract on license can be applied to the termination of a franchise agreement in an analogous manner (Tomić, 1986:95). However, as there is no domestic (R. Serbia) positive legal regulations on franchising agreements, the court would have to take into account the possibility of analogous application of the provisions in each concrete case, as follows: a) on the termination of a commercial agency, or b) a licensing agreement, as general provisions on permanent obligations (Миљковић, 2014:355). One of possible solutions in such cases, to prevent occurring of an impossible situation because of the specificities of a franchising agreement, is to oblige the court to take into consideration the expert literature, which deals with this matter using the comparative method, when solving the termination of a franchising agreement (Париводић, 2004:289).

1 The receiver of franchise - Franchisee uses a developed business operations method and the know-how developed by the grantor of franchise - Franchisor, and also specific forms of intellectual property.

2 Law on Contracts and Torts (hereinafter: LCT), „Official Gazette of the SFR of Yugoslavia”, 29/78, 39/85, 45/89 - Decision of the Constitutional Court of Yugoslavia and 57/89, „Official Gazette of the FR of Yugoslavia”, 31/93, 22/99, 23/99, 35/99, 44/99 and „Official Gazette of Serbia and Montenegro", 1/2003 - Constitutional Charter, Retrieved 19 November 2018 from https://www.mpravde.gov.rs/files/The $\% 20$ Law $\% 20$ of $\% 20$ Contract $\% 20$ and $\% 20$ Torts_180411.pdf 
A franchising agreement, as all civil law and autonomous commercial law contracts, may be terminated, as follows: 1) with the regular passage of the term for which it is concluded, ${ }^{3}$ and 2 ) cancellation. ${ }^{4}$

\section{Termination of Agreement with the Passage of Term it is Concluded for}

The termination of a franchising agreement with the passage of the term it was concluded for, represents a common way of termination of a contractual relationship. This mode of termination of an agreement is in compliance with all the generally accepted principles of contract law. With the expiration of the term to which it was concluded for, the franchising agreement ceases automatically. When the agreement terminates with the passage of the term it was concluded for, weather the reasons for the termination of the agreement, are serious or justified are not taken consideration. ${ }^{5}$

For the contracting parties, and particularly for the franchisee, it is important to set: a) minimum fixed time limit for the term and b) clause on renewal of the agreement.

\subsection{Is the contractual provision for a minimum fixed term agreement necessary?}

A franchising agreement, as well as all other contracts regardless whether they belong to classic law contracts or modern autonomous commercial contracts law, is concluded for a specific time period. The term of duration is implicated by an economic causa that represents the foundation for concluding a franchising agreement. The economic causa or the size of funds invested (of the franchisor and the franchisee) represents the starting foundation that is taken into consideration when the duration of a franchising agreement is established. When concluding a franchising agreement, and on the basis of the conducted economic analysis franchisee, wants to: a) realise depreciation of invested funds within

3 „a permanent debit relationship within a specified period shall come to an end on the expiration of the relevant time limit..." - Art. 357, LCT, „Official Gazette of the SFR of Yugoslavia”, 29/78, 39/85, 45/89 - Decision of the Constitutional Court of Yugoslavia and 57/89, „Official Gazette of the FR of Yugoslavia”, 31/93, 22/99, 23/99, 35/99, 44/99 and „Official Gazette of Serbia and Montenegro", 1/2003 - Constitutional Charter, Retrieved 19 November 2018 from https://www.mpravde.gov.rs/files/The\%20Law $\% 20$ of $\% 20$ Contract $\% 20$ and $\% 20$ Torts_180411.pdf

4 Cancellation represents a forced termination of agreement when the contractual provisions are violated.

5 The same effect occurs if the agreement became invalid through an agreement of the contracting parties. 
a specified time period; and b) start realising the specified profit (Миљковић, 2014:353). The depreciation period and the commencement of the realisation of profit is not the same with all manifesting forms of franchising agreements. ${ }^{6}$ These two basic economic criteria represent the benchmarks for the franchisee when establishing the term of an agreement.

In regard to the duration of an agreement, the British Franchise Association $\mathrm{BFA}^{7}$ lays down that the duration of the franchising agreement should be that the minimum term for a franchise contract should be the period necessary to amortize those of a franchisee's initial investment which are specific to the franchise. Although the aforementioned ethical principle is contained in the BFA Code of Ethics, it generates certain unclearness. The BFA has clarified it in details by integrating the Extension and Interpretation to the Code of Ethics, ${ }^{8}$ which lays down in the following: 1 ) that for a minority of the largest franchise opportunities, amortizing initial investments may not be a primary objective for the franchisee. In such cases, the objective should be to adopt a contract period which reasonably balances the interests of the parties to the contract and 2) that this section could be subject to national laws concerning the restraint of trade and may need to be met through renewal clauses. ${ }^{9}$

Following the tendencies of contemporary legislative solutions, the Working Document Civil Code ${ }^{10}$ provide that with a franchising agreement concluded for a fixed term period, the duration of the agreement should be long enough to allow the franchisee to make a return on their invested funds. ${ }^{11}$ Although the possibility for a contract to be concluded for a fixed term is stipulated in the aforementioned solution of the provisions of the Working Document Civil Code, and in the circumstances when franchising business is not sufficiently developed

6 Depending on the form of appearance of the concerned franchise agreement, a minimum fixed term ranges from one to five years, while the maximum one depends on the contracting parties' interests in priority.

7 See more about on, Retrieved 05, August 2018, from https://www.thebfa.org/

8 The European Code of Ethics for Franchising \& its national Extensions \& Interpretations, Retrieved 05, August 2018, from http://www.eff-franchise.com/Data/Code\%20of\%20 Ethics.pdf

9 The European Code of Ethics for Franchising \& its national Extensions \& Interpretations, Retrieved 05, August 2018, from http://www.eff-franchise.com/Data/Code $\% 20$ of $\% 20$ Ethics.pdf 7

10 Civil Code of the Republic of Serbia - Working Document, Belgrade 29. May 2015, Retrieved 02, August 2018, from https://www.mpravde.gov.rs/files/NACRT.pdf

11 Art. 1288 para. 2, Civil Code of the Republic of Serbia - Working Document, Belgrade 29. May 2015, Retrieved 02, August 2018, from https://www.mpravde.gov.rs/files/NACRT.pdf 
in the Republic of Serbia, ${ }^{12}$ it is possible for the franchisor to undertake a series of fraudulent actions to the prejudice of the franchisee.

\subsection{Renewal Clause}

The position of the franchisee in a franchise relationship depends also on whether the agreement provides for the renewal clause. ${ }^{13}$ By entering the renewal clause, ${ }^{14}$ after the expiration of the term of the agreement, it is automatically extended for the period contained in the basic agreement. The renewal clause, creates a contractual relationship for indefinite time period. The renewal clause enables the franchisee to use the right to option, whether he continues to participate in the franchise relationship or they will step out of that relationship by their own free will.

Although the renewal clause represents an ideal option for the franchisee to renew the agreement in compliance with their business interests, the question arises whether it is being renewed under the same or changed terms and conditions. The provisions of the Working Document Civil Code stipulate that the franchisee who regularly performed their contractual obligations has the right to conclude the agreement to a new term under the same terms and conditions. ${ }^{15}$ Some franchisor dislike approving a too-long term of the agreement as they believe amendments to the law may occur and they would prefer to have an option to respond earlier and not later, accordingly (Mendelsohn et. al., 2004:363).

The franchisee will not be able to renew the contract although they are entitled to, when the franchisor assesses that the market where the franchisee operates on or they operate on is not economically cost-effective any longer (Mendelsohn

12 See more about on, Retrieved 05, August 2018, from http://www.pks.rs/MSaradnja. aspx?id $=679 \& p=0 \&$

13 The renewal clause is a standard contractual provision regardless of the form of the appearance form of a franchise agreement.

14 The BFA Code requires that every agreement contains the ground for renewal of the agreement. The basis for contract renewal should take into account the length of the original term, the extent to which the contract empowers the franchisor to require investments from the franchisee for relinquishment or renovation, and the extent to which the franchisor may vary the terms of a contract on renewal. The overriding objective is to ensure that the franchisee has the opportunity to recover his franchise specific investments, both initial and subsequent ones, and to exploit the franchised business for as long as the contract persists. - The European Code of Ethics for Franchising \& its national Extensions \& Interpretations, Retrieved 05, August 2018, from http://www.eff-franchise.com/Data/Code $\% 20$ of $\% 20$ Ethics.pdf 8.

15 Art. 1289 para. 1, Civil Code of the Republic of Serbia - Working Document, Belgrade 29. May 2015, Retrieved 02, August 2018, from https://www.mpravde.gov.rs/files/NACRT.pdf 
et. al., 2004:367). At the moment when the franchisor makes the decision not to extend the agreement, he is obliged to pay a reasonable compensation to the franchisee for the value of the franchise unit. The provisions of the Working Document Civil Code stipulate that in the event of termination of an agreement in this manner, the franchisee is entitled to compensation for increasing the value and the business image of the franchise system - the compensation for the increased goodwill - if the contributed to a significant volume of business of the franchisor and the business image of the franchise network throughout the term of the agreement. ${ }^{16}$

\section{Unilateral Repudiation (cancellation) of the Agreement}

The termination of an agreement through a cancellation occurs in all those cases when one contracting party repudiates the agreement for the violation of contractual provisions by the other contracting party that commits the violation of contractual provisions through an act or omission to act. In all these cases, where there is no consensual agreement repudiation, and the repudiation is requested by one of the contracting parties prior to the expiration of the contractual term ${ }^{17}$ or where the agreement was concluded for an indefinite term, and the agreement ceases due to a cancellation of agreement as the result of the violation of rights and obligations thereof.

Cancellation of agreement can be: a) ordinary notice or b) extraordinary cancellation.

\subsection{Ordinary notice}

An ordinary notice is an instrument for terminating a permanent contractual relationship. The notice is a legally relevant declaration of will of one to the other contracting party granted on the basis of legal power (agreement or law) where the agreement concluded for an indefinite time period unilaterally terminates. On the basis of the provisions of the LCT, the debit relationship comes to an

16 Art. 1289 para. 2, Civil Code of the Republic of Serbia - Working Document, Belgrade 29. May 2015, Retrieved 02, August 2018, from https://www.mpravde.gov.rs/files/NACRT.pdf $17, \ldots$ should prior to the expiration of the time limit for performing the obligation it become obvious that one party is not going to meet his contractual obligation, the other party may repudiate the contract and claim damages.“ - Art. 128, LCT., „Official Gazette of the SFR of Yugoslavia", 29/78, 39/85, 45/89 - Decision of the Constitutional Court of Yugoslavia and 57/89, „Official Gazette of the FR of Yugoslavia”, 31/93, 22/99, 23/99, 35/99, 44/99 and „Official Gazette of Serbia and Montenegro", 1/2003 - Constitutional Charter, Retrieved 19 November 2018 from https://www.mpravde.gov.rs/files/The\%20Law\%20of\%20Contract\%20and\%20 Torts_180411.pdf 
end on the expiration of a cancellation time limit specified by contract; and if such a time limit is not specified by contract, the relationship comes to an end on the expiration of the time limit specified by statute or trade practice. ${ }^{18}$ The notice may be given at any time, but not at a bad time; ${ }^{19}$ given in a written form (in order to produce effect); and the notice term begins to run at the moment when the notice reaches the other contracting party. The contracting parties may stipulate in the agreement that their debit relationship ceases with the delivery of notice, unless something else is specified by statute for a specific case. $^{20}$ The creditor is entitled to request from the debtor what is due prior to the termination of liabilities on the ground of expiration of the time limit or the cancellation thereof. ${ }^{21}$

In regard to the termination of agreement, the LCT starts from the principle pacta sunt servanda. ${ }^{22}$ On the basis of the postulated principle, it may be concluded that the LCT provides for a possibility of ordinary notice as a unilateral mechanism for terminating permanent debit relationships concluded for indefinite time period. With Art. 358 paragraph 1. of the LCT, that if the time period of the duration of debit relationship is not specified, each party may terminate it with a notice. On the basis of the aforementioned provision, which

18 Art. 358 para. 4, LCT., „Official Gazette of the SFR of Yugoslavia”, 29/78, 39/85, 45/89 Decision of the Constitutional Court of Yugoslavia and 57/89, "Official Gazette of the FR of Yugoslavia", 31/93, 22/99, 23/99, 35/99, 44/99 and "Official Gazette of Serbia and Montenegro", 1/2003 - Constitutional Charter, Retrieved 19 November 2018 from https://www.mpravde. gov.rs/files/The\%20Law\%20of\%20Contract\%20and\%20Torts_180411.pdf

19 Art. 358 para. 3, LCT., „Official Gazette of the SFR of Yugoslavia”, 29/78, 39/85, 45/89 Decision of the Constitutional Court of Yugoslavia and 57/89, „Official Gazette of the FR of Yugoslavia", 31/93, 22/99, 23/99, 35/99, 44/99 and "Official Gazette of Serbia and Montenegro", 1/2003 - Constitutional Charter, Retrieved 19 November 2018 from https://www.mpravde. gov.rs/files/The\%20Law\%20of\%20Contract\%20and\%20Torts_180411.pdf

20 Art. 358 para. 5, LCT., „Official Gazette of the SFR of Yugoslavia”, 29/78, 39/85, 45/89 Decision of the Constitutional Court of Yugoslavia and 57/89, „Official Gazette of the FR of Yugoslavia", 31/93, 22/99, 23/99, 35/99, 44/99 and "Official Gazette of Serbia and Montenegro", 1/2003 - Constitutional Charter, Retrieved 19 November 2018 from https://www.mpravde. gov.rs/files/The\%20Law\%20of\%20Contract\%20and\%20Torts_180411.pdf

21 Art. 358 para. 6, LCT., „Official Gazette of the SFR of Yugoslavia”, 29/78, 39/85, 45/89 Decision of the Constitutional Court of Yugoslavia and 57/89, "Official Gazette of the FR of Yugoslavia", 31/93, 22/99, 23/99, 35/99, 44/99 and "Official Gazette of Serbia and Montenegro", 1/2003 - Constitutional Charter, Retrieved 19 November 2018 from https://www.mpravde. gov.rs/files/The\%20Law\%20of\%20Contract\%20and\%20Torts_180411.pdf

22 Art. 17 para. 2, LCT., „Official Gazette of the SFR of Yugoslavia”, 29/78, 39/85, 45/89 Decision of the Constitutional Court of Yugoslavia and 57/89, „Official Gazette of the FR of Yugoslavia", 31/93, 22/99, 23/99, 35/99, 44/99 and "Official Gazette of Serbia and Montenegro", 1/2003 - Constitutional Charter, Retrieved 19 November 2018 from https://www.mpravde. gov.rs/files/The\%20Law\%20of\%20Contract\%20and\%20Torts_180411.pdf 
can be analogously applied to a franchising agreement, each contracting party is entitled - in the event that the agreement is concluded for an indefinite time period - to terminate the agreement with an ordinary notice at the moment they evaluate it as suitable.

However, one of the basic characteristics of a franchising agreement is that it is hardly ever concluded for an indefinite time period. The franchising agreement is most frequently concluded for a definite time period with a renewal possibility. With Article 357 of the LCT, a permanent debit relationship with a definite term limit ceases when the time limit expires, unless it is agreed or laid down by the law that following the expiry of the term, the debit relationship is extended for an indefinite time period unless cancelled in timely manner. It can be concluded on the basis of the aforementioned provision that the law does not provide for the tacita reconductio principle as a general solution for permanent debit relationships; thus, if the agreement does not provide for the extension mechanism, the question arises whether this institute provided for a licensing agreement, Article 709 paragraph 1 of the LCT, can be analogously applied thereof (Париводић et. al., 2004:289).

Besides the general provisions of the LCT which are applied to an ordinary cancellation, the application of the provisions which refer to commercial agency ${ }^{23}$ and licensing agreement ${ }^{24}$ is also possible. Yet, in addition to analogous application of the provisions on commercial agency and licensing agreements, a question also arises what if the agreement does not provide for a period of notice. According to the LCT provisions, a notice period for the termination of a contract of commercial agency must be communicated to the other party at least one month

23 "By a contract of commercial agency the agent shall assume the obligation to take permanent care that third persons enter into contracts with his principal, and to mediate in that respect between them and the principal, as well as to enter into contracts, after obtaining authorisation, with third persons on behalf and for the account of the principal, while the principal shall assume the obligation to pay to him, for each contract concluded, an agreed fee (brokerage)...” - Art. 790, LCT. „Official Gazette of the SFR of Yugoslavia”, 29/78, 39/85, 45/89 - Decision of the Constitutional Court of Yugoslavia and 57/89, "Official Gazette of the FR of Yugoslavia”, 31/93, 22/99, 23/99, 35/99, 44/99 and „Official Gazette of Serbia and Montenegro", 1/2003 - Constitutional Charter, Retrieved 19 November 2018 from https:// www.mpravde.gov.rs/files/The\%20Law\%20of\%20Contract\%20and\%20Torts_180411.pdf

24 "By a licensing agreement a licensor shall assume the obligation to assign to a licensee, entirely or partially, the right of use (franchise) of an invention, technical know-how and experience, trade-mark, sample or model, while the licence shall assume the obligation to pay a specified fee in return” - Art. 686, LCT. „Official Gazette of the SFR of Yugoslavia”, 29/78, 39/85, 45/89 - Decision of the Constitutional Court of Yugoslavia and 57/89, „Official Gazette of the FR of Yugoslavia”, 31/93, 22/99, 23/99, 35/99, 44/99 and „Official Gazette of Serbia and Montenegro", 1/2003 - Constitutional Charter, Retrieved 19 November 2018 from https:// www.mpravde.gov.rs/files/The\%20Law\%20of\%20Contract\%20and\%20Torts_180411.pdf 
prior to the expiration of calendar quarter, and if the contract has lasted for three years, the other party must be given notice two months prior to the expiration of calendar year. ${ }^{25}$ However, with licensing agreements if the notice period is not stipulated by agreement, it shall be six months, provided the licensor does not cancel the agreement during the first year of its validity. ${ }^{26}$ Article 710 paragraph 2 of the LCT referring to a licensing agreement is in favour of the franchisee as it provides them with certain legal security, such as: a) the notice period is six months and b) the licensor/the franchisor cannot cancel the agreement during the first year of its validity. With the application of the mentioned provisions, the economic interests of the franchisee are protected, leaving him enough space to amortise the invested investment funds. Although the application of provisions on the notice period, which refers to licensing agreement provided for in (Article 710) of the LCT would be in favour of the franchisee, certain situations may occur when the shorter notice period is in favour of the franchisor, the provisions referred to in (Article 810) of the LCT related to cancellation of agreement on commercial agency should apply.

\subsection{Extraordinary cancellation}

Extraordinary cancellation as a mechanism of terminating continuous contractual relationships (permanent contract) occurs in all those situations when one contracting party fails to meet their obligation, where a serious violation of contractual obligations occurs. ${ }^{27}$ Serious violation of contractual obligations happens by ruining mutual trust of contracting parties. When mutual trust is violated by certain improper behaviour by the other contracting party, it may represent a serious cause for terminating an agreement, a serious cause always has its grounds in the principles of thoroughness and honesty (Draškić, 1983:60).

25 Art. 810 para. 2, LCT., „Official Gazette of the SFR of Yugoslavia”, 29/78, 39/85, 45/89 Decision of the Constitutional Court of Yugoslavia and 57/89, "Official Gazette of the FR of Yugoslavia", 31/93, 22/99, 23/99, 35/99, 44/99 and "Official Gazette of Serbia and Montenegro", 1/2003 - Constitutional Charter, Retrieved 19 November 2018 from https://www.mpravde. gov.rs/files/The\%20Law\%20of\%20Contract\%20and\%20Torts_180411.pdf

26 Art. 710 para. 2, LCT., „Official Gazette of the SFR of Yugoslavia”, 29/78, 39/85, 45/89 Decision of the Constitutional Court of Yugoslavia and 57/89, "Official Gazette of the FR of Yugoslavia", 31/93, 22/99, 23/99, 35/99, 44/99 and "Official Gazette of Serbia and Montenegro", 1/2003 - Constitutional Charter, Retrieved 19 November 2018 from https://www.mpravde. gov.rs/files/The\%20Law\%20of\%20Contract\%20and\%20Torts_180411.pdf

27 A serious violation of contractual obligations means violations of those contractual obligations which represent the essence of a contractual relationship upon which it rests. 


\subsubsection{The application of general and special provisions of the Law on Contracts and Torts (LCT)}

The application of general and special provisions of the LCT to the termination of a franchising agreement due to extraordinary cancellation is possible. ${ }^{28}$ According to the provision of the LCT each party may repudiate the contract without a period of notice on the ground of serious causes, which must be stated. ${ }^{29} \mathrm{On}$ the basis of the mentioned provision, it is concluded that the repudiation occurs with immediate effect, there is no notice period, since the cause is so grave that the party stating the causes cannot expect the other party to continue the contractual relationship. With further application of the provisions of the LCT, it is stipulated that if the statement of repudiation of contract is made with no serious reasons, it shall be considered as a notice with the regular period of notice. ${ }^{30}$ LCT stipulate the protection of one contracting party against any potential unconscientious behaviour of the other contracting party, foreseeing that an unfounded notice shall entitle the other party to repudiate the contract without notice. ${ }^{31}$ In the event that one contracting party has repudiated the

28 „1) Should in a contract with consecutive obligations one party fail to perform one obligation, the other party may, in a reasonable time limit, repudiate the contract regarding all future obligations, should existing circumstances obviously indicate that they, too, are not going to be performed.

(2) That party may repudiate the contract not only regarding future obligations, but also regarding obligations already performed should their performance alone be of no interest to him.

(3) The defaulter may preserve the contract after supplying an adequate guarantee. " Art. 129, LCT., „Official Gazette of the SFR of Yugoslavia”, 29/78, 39/85, 45/89 - Decision of the Constitutional Court of Yugoslavia and 57/89, „Official Gazette of the FR of Yugoslavia”, 31/93, 22/99, 23/99, 35/99, 44/99 and "Official Gazette of Serbia and Montenegro", 1/2003 - Constitutional Charter, Retrieved 19 November 2018 from https://www.mpravde.gov.rs/ files/The\%20Law\%20of\%20Contract\%20and\%20Torts_180411.pdf

29 Art. 811 para. 1, LCT., „Official Gazette of the SFR of Yugoslavia”, 29/78, 39/85, 45/89 Decision of the Constitutional Court of Yugoslavia and 57/89, „Official Gazette of the FR of Yugoslavia", 31/93, 22/99, 23/99, 35/99, 44/99 and "Official Gazette of Serbia and Montenegro", 1/2003 - Constitutional Charter, Retrieved 19 November 2018 from https://www.mpravde. gov.rs/files/The\%20Law\%20of\%20Contract\%20and\%20Torts_180411.pdf

30 Art. 811 para. 2, LCT., „Official Gazette of the SFR of Yugoslavia”, 29/78, 39/85, 45/89 Decision of the Constitutional Court of Yugoslavia and 57/89, „Official Gazette of the FR of Yugoslavia", 31/93, 22/99, 23/99, 35/99, 44/99 and "Official Gazette of Serbia and Montenegro", 1/2003 - Constitutional Charter, Retrieved 19 November 2018 from https://www.mpravde. gov.rs/files/The\%20Law\%20of\%20Contract\%20and\%20Torts_180411.pdf

31 Art. 811 para. 4, LCT., „Official Gazette of the SFR of Yugoslavia”, 29/78, 39/85, 45/89 Decision of the Constitutional Court of Yugoslavia and 57/89, "Official Gazette of the FR of Yugoslavia", 31/93, 22/99, 23/99, 35/99, 44/99 and "Official Gazette of Serbia and Montenegro", 
agreement, without the existence of serious causes, they are obliged to compensate damages to the other contracting party. However, if the contract is repudiated on reasonable grounds, due to serious causes, they are entitled to damages by the other contracting party. ${ }^{32}$ In regard to damages, this refers to the compensation of positive contractual interest of the injured party (simple loss - damnum emergens and profit lost - lucrum cessans). ${ }^{33}$ A creditor shall be entitled to compensation for damnum emergens ${ }^{34}$ and lucrum cessans, ${ }^{35}$ which at the time of entering into contract should have been foreseen by the debtor as a possible consequence of breach of the contract, having regard to facts known to

1/2003 - Constitutional Charter, Retrieved 19 November 2018 from https://www.mpravde. gov.rs/files/The\%20Law\%20of\%20Contract\%20and\%20Torts_180411.pdf

32 „An agent whose activity is interrupted due to an unfounded notice shall be entitled to compensation to cover his lost commission, and should he cancel the contract without grounds, the right to redress shall belong to the principal“ - Art. 811 para. 3, LCT., „Official Gazette of the SFR of Yugoslavia", 29/78, 39/85, 45/89 - Decision of the Constitutional Court of Yugoslavia and 57/89, „Official Gazette of the FR of Yugoslavia”, 31/93, 22/99, 23/99, 35/99, 44/99 and "Official Gazette of Serbia and Montenegro", 1/2003 - Constitutional Charter, Retrieved 19 November 2018 from https://www.mpravde.gov.rs/files/The\%20Law\%20 of\%20Contract\%20and\%20Torts_180411.pdf

33 „Injury or loss shall be a diminution of someone's property (simple loss) and preventing its increase (profit lost) ..." - Art. 155, LCT., „Official Gazette of the SFR of Yugoslavia”, 29/78, 39/85, 45/89 - Decision of the Constitutional Court of Yugoslavia and 57/89, „Official Gazette of the FR of Yugoslavia”, 31/93, 22/99, 23/99, 35/99, 44/99 and „Official Gazette of Serbia and Montenegro", 1/2003 - Constitutional Charter, Retrieved 19 November 2018 from https:// www.mpravde.gov.rs/files/The\%20Law\%20of\%20Contract\%20and\%20Torts_180411.pdf

34 „The amount of damages shall be determined according to prices at the time of the rendering court's decision, unless something else be ordered by law“ - Art. 189 LCT.; See „... while also taking into account the circumstances after the occurrence of damage, the court shall determine damages in the amount necessary to restore the material state of the person sustaining damage into the state it would have been without the damaging act or omission" - Art. 190, LCT., „Official Gazette of the SFR of Yugoslavia”, 29/78, 39/85, 45/89 - Decision of the Constitutional Court of Yugoslavia and 57/89, „Official Gazette of the FR of Yugoslavia”, 31/93, 22/99, 23/99, 35/99, 44/99 and "Official Gazette of Serbia and Montenegro", 1/2003 - Constitutional Charter, Retrieved 19 November 2018 from https://www.mpravde.gov.rs/ files/The\%20Law\%20of\%20Contract\%20and\%20Torts_180411.pdf

35 „In assessing the amount of the profit lost the profit which was reasonably expected according to the regular course of events or particular circumstances, and whose realization has been prevented by an act or omission of the tortfeasor shall be taken into account" - Art. 189 para. 3, LCT., „Official Gazette of the SFR of Yugoslavia”, 29/78, 39/85, 45/89 - Decision of the Constitutional Court of Yugoslavia and 57/89, „Official Gazette of the FR of Yugoslavia”, 31/93, 22/99, 23/99, 35/99, 44/99 and "Official Gazette of Serbia and Montenegro", 1/2003 - Constitutional Charter, Retrieved 19 November 2018 from https://www.mpravde.gov.rs/ files/The\%20Law\%20of\%20Contract\%20and\%20Torts_180411.pdf 
him at the time or which should have been known to him. ${ }^{36}$ In the event of fraud or intentional default due to gross negligence, the creditor is entitled to request from the debtor the reimbursement of entire damage caused by the contract violation, irrespective of the debtor's ignorance of those special circumstances by reason of which they have occurred. ${ }^{37}$

A question arises what happens if: a) a serious cause is not specified by the agreement, and it is in the interest of the franchisee; or b) what if a situation that is not a serious cause is foreseen by the agreement but the franchisor stated it in the agreement. In the first case, if a serious cause is not foreseen by the agreement, and it is in the interest of the franchisee, he may refer to the existence of a serious cause for the repudiation of agreement. ${ }^{38}$ In the second case, the franchisor considering his economic dominance, may also foresee in the agreement the causes that do not represent serious causes for the repudiation of agreement but are in his interest. In such circumstances, in compliance with Article $143,{ }^{39}$ the court may reject the application of such provisions of the agreement. It is possible to stipulate an expansion of the circle of serious reasons by contractual provisions, whereby this expansion is acceptable if it does not

36 Art. 266 para. 1, LCT., „Official Gazette of the SFR of Yugoslavia”, 29/78, 39/85, 45/89 Decision of the Constitutional Court of Yugoslavia and 57/89, „Official Gazette of the FR of Yugoslavia", 31/93, 22/99, 23/99, 35/99, 44/99 and "Official Gazette of Serbia and Montenegro", 1/2003 - Constitutional Charter, Retrieved 19 November 2018 from https://www.mpravde. gov.rs/files/The\%20Law\%20of\%20Contract\%20and\%20Torts_180411.pdf

37 Art. 266 para. 2, LCT., „Official Gazette of the SFR of Yugoslavia”, 29/78, 39/85, 45/89 Decision of the Constitutional Court of Yugoslavia and 57/89, "Official Gazette of the FR of Yugoslavia", 31/93, 22/99, 23/99, 35/99, 44/99 and "Official Gazette of Serbia and Montenegro", 1/2003 - Constitutional Charter, Retrieved 19 November 2018 from https://www.mpravde. gov.rs/files/The\%20Law\%20of\%20Contract\%20and\%20Torts_180411.pdf

$38, \ldots$ each party may repudiate the contract without a period of notice on the ground of serious causes, which must be stated. “ - Art. 811 para. 1, LCT., „Official Gazette of the SFR of Yugoslavia", 29/78, 39/85, 45/89 - Decision of the Constitutional Court of Yugoslavia and 57/89, „Official Gazette of the FR of Yugoslavia”, 31/93, 22/99, 23/99, 35/99, 44/99 and „Official Gazette of Serbia and Montenegro", 1/2003 - Constitutional Charter, Retrieved 19 November 2018 from https://www.mpravde.gov.rs/files/The\%20Law\%20of\%20Contract $\% 20$ and $\% 20$ Torts_180411.pdf

39 „The court may deny application of specific provisions of the general terms and conditions precluding the other party to raise demurrers, or of those on the ground of which such party is left without contractual rights or loses time limits, or those which are otherwise unjust or excessively strict towards such party“ - Art. 143 para. 2, LCT., „Official Gazette of the SFR of Yugoslavia", 29/78, 39/85, 45/89 - Decision of the Constitutional Court of Yugoslavia and 57/89, „Official Gazette of the FR of Yugoslavia”, 31/93, 22/99, 23/99, 35/99, 44/99 and „Official Gazette of Serbia and Montenegro", 1/2003 - Constitutional Charter, Retrieved 19 November 2018 from https://www.mpravde.gov.rs/files/The\%20Law\%20of\%20Contract\%20and\%20 Torts_180411.pdf 
represent an excuse for leaving the relationships for the sake of another reason (Париводић, 2004:294).

The question arises what will happen if there are constancy and continuity of minor violations of the contractual obligations by the franchisee. Minor violations of contractual obligations in a continuous and constant manner, result in franchisor right to extraordinary cancellation, because they are not eliminated within the contractually stipulated time limit. Such minor violations of contractual obligations by the franchisee and their non-elimination represent a negligent attitude and disrespect of the other contracting party.

\subsection{Serious reasons for cancellation of contract}

Extraordinary cancellation franchising agreement is only possible in the event of occurrence of serious reasons (good causes) (Миљковић, 2014:365). Good causes are those reasons whose occurrence seriously violates the essential provisions of the agreement. The franchisor is obliged to stipulate in the draft agreement which violations of contractual provisions are considered serious reasons for extraordinary notice. If such reasons are stipulated in the $\mathrm{draft}$ agreement delivered to them (and later they have also accessed to the agreement) the franchisee has no possibility to refer to being misled thereof, and that if they were aware of the given requirements, would not access the agreement either (Миљковић, 2014:366).

\subsubsection{Classified serious reasons}

Serious reasons may be classified into two groups, as follows: a) the reasons that exist in the pre-phase of an independent commencement of business operations of the franchisee, and b) the reasons that exist in the phase of independent business operations of the franchisee.

Pre-phase of an independent commencement of business - The reasons that exist may refer to: a) training of the franchisee and b) franchise fee - initial fee. In the training phase, the franchisor is obliged to provide adequate training to the franchisee so that they can independently operate in agreement with the relinquished business method and business principles of the franchise network. The franchisor, in compliance with their own business experience, conducts the assessment of the business skills in the training phase, and on the basis thereof they assess whether the franchisee is capable to provide the expected contribution to the franchise network. If franchisee is assessed in the training phase as not capable to operate in expected manner in the future, the franchisor exercises the right to extraordinary cancellation of agreement. 
Having accessed the franchise network, the franchisee is obliged to pay the initial fee and initial insurance premium. The initial fee and the initial insurance premium are the determined as conditional fees. The fees are to be paid by the franchisee in order to commence their independent business operations. Failure to pay the mentioned fees in the accessing phase, entitles the franchisor to exercise extraordinary cancellation of agreement due to the occurrence of serious reasons.

Independent business operations - The franchisee is obliged to adhere to contractual provisions and to carry out the undertaken commitments thereof, operating in line with the relinquished business method. Significant violation of contractual provisions may occur when ${ }^{40}$ the relinquished licensed rights are abused. The abuse or inadequate use of license rights may refer to: 1) copyrights, 2) industrial property rights; 3) trademark; 4) license; 5) know-how, and all the other rights that make the franchise operations specific. The abuse of contractual provisions that constitute the essence of franchise operations represent a serious reason for extraordinary notice of cancellation. The violation of agreement refer to: 1) sales of goods or rendering services beyond the contractual area; 2) sales of non-exclusive goods; ${ }^{41} 3$ ) disclosure of a business secret; 4) failure to pay continuous franchise fee; 5) failure to pay fee for advertising, etc.

The reasons that do not directly refer to the violation of relevant contractual provisions, may also occur as serious reasons for extraordinary cancellation. The reasons that are not related to the agreement and represent serious reasons are: 1) bankruptcy of the franchisee; 2) illiquidity; 3) criminal verdict against the franchisee and the loss of the right to use a business unit (Tomić, 1986:97, Draškić, 1983:60-66).

Although there are serious reasons in favour of the franchisor, it should be pointed out that there are also serious reasons in favour of the franchisee. The franchisee may only use the right to extraordinary cancellation if the franchisor causes the occurrence of relevant violations of contractual provisions (inadequate training, failure to transfer know how, failure to transfer license rights, failure to transfer business secret, etc.) or due to their insolvency and bankruptcy. The franchisee rights to extraordinary repudiation of agreement are significantly narrower in relation to the franchisor's rights. Irrespective of the fact that the rights to unilateral repudiation are narrower, they are significant for the franchisee because they get an impression of legal security.

40 No intention is needed to exercise any right inadequately, the mere fact that it is inadequately exercised is sufficient.

41 Goods purchased from another supplier, and not from the franchisor or the entity, i.e. the supplier determined by the franchisor. 


\subsubsection{Whether serious reasons imply automatic cancellation of the contract}

A question arises whether the occurrence of contractually stipulated serious reasons automatically generates the cancellation of agreement or not. Serious reasons are classified as curable or incurable (Mendelsohn, 2004:371). All serious reasons can be classified into two groups: a) those leading to an automatic cancellation of agreement; and b) those leading to cancellation of agreement following the expiration of additional time limit.

The reasons leading automatically to the cancellation of agreement are: 1) abuse of copyrights and industrial property rights; 2) disclosure of business secret; and 3) disclosure of know how.

The other reasons - although falling into the category of serious reasons - do not lead automatically to the cancellation of agreement, but only after the expiration of the additional time limit. The franchisor leaves additional adequate time limit to the franchisee during which they should eliminate the consequences of the results occurred, which represent the basis for an extraordinary cancellation of agreement. For example: if franchisee is late with the payment or does not pay entirely the continuous franchising fee within the specified period due to certain objective or subjective circumstances, and the franchisor leaves an additional time limit within which the franchisee is obliged to pay franchise fee entirely. The franchisor will not cancel the franchise agreement until the moment the sum of non-paid continuous fees reaches the critical level which burdens the franchisor's business operations. For example: when the franchisor conducts a control of business operations and quality, and observes certain deficiencies, they leave an additional time limit to the franchisee within which they are obliged to eliminate the observed inconsistencies - deficiencies in business operations in accordance with the instructions. Although above mentioned are classified as serious reasons, they hardly ever lead to an automatic cancellation of agreement, only if the franchisee does not eliminate or does not performs the undertaken commitments within the additional time limit.

\section{Conclusion}

Issues that imply the termination of the agreement, require the need for additional more precise forecasting inside the franchise agreement. It is always necessary to start from the point of view that the contracting parties know what is the best for them. The tendency for the agreement to regulate more effectively the issue of termination of the contract is of importance because of the dominance of the franchisor. The franchisor, using the franchisee's lack of knowledge on franchising, often abuses his dominant position. One should always be guided by the principle of pacta sunt servanda. The dominant position of the franchisor, 
the lack of the developed business and court practice in R. Serbia questions the merits of the principle of pacta sunt servanda.

The franchisee as an inferior contracting party, often due to ignorance, oversees the Institute: a) the minimum fixed term of the agreement and b) good cause. By contractually forecasting the minimum fixed term of the agreement, the franchisee is on one hand guaranteed on one hand to depreciate the invested investment funds and start to gain profit, while on the other hand it is guaranteed that the franchisor will not be able to unilaterally terminate the agreement. Failure to anticipate a minimum fixed term of the agreement franchisee does not guarantee the franchisee to exercise the above rights. In addition, the contractual failure to anticipate the minimum fixed term, in the event of termination, leaves the franchisee to an uncertain and often unfair decision of the court. This is particularly, the case in countries with underdeveloped jurisprudence in the field of franchising business such as R. Serbia. It is in the interests of the contracting parties to foresee the serious causes (good cause) of the cancellation of the agreement. Good cause prevents fraudulent actions on both the franchisor and franchisees. The contractual prediction of good cause the basis of the cancellation of the agreement is specified.

Until the moment of enactment and entry into force of the Civil Code of the Republic of Serbia, in view of the termination of the franchising agreement, it is necessary to apply the general legal provisions contained in the Law on Contracts and Torts. Also, in addition to the application of general legal regulations, when termination of the franchising agreement, it is advisable to apply legal provisions relating to the termination of the agreement on commercial representation and the license agreements contained in the Law on Contracts and Torts. Only by applying the above rules, in the current circumstances, with the existence of a legal vacuum, all doubts about the regular termination and cancellation of the franchise agreement will be removed.

\section{References}

Draškić, M., (1983). Ugovor o franšizingu, Institut društvenih nauka-Centar za pravna i politikološka istraživanja, Beograd

Mendelsohn, M., ed. (2004). Franchising Law, Second Edition, Richmond Law \& Tax Ltd, London, UK.

Миљковић, С., (2014). Правни односи код уговора о франшизингу, Докторска дисертација, Универзитет у Новом Саду Правни факултет, Нови Сад.

Париводић, М., (2004). Право међународног франшизинга, Службени гласник, Београд. 
Mlikotin-Tomić. D., (1986). Ugovor o franchisingu, Informer, Zagreb.

The European Code of Ethics for Franchising \& its national Extensions \& Interpretations, Retrieved 05 August 2018 from http://www.eff-franchise.com/ Data/Code\%20of\%20Ethics.pdf

The British Franchise Association (BFA), https://www.thebfa.org/, Accesseed 05 August 2018

Zakon o obligacionim odnosima (The Law of Contract and Torts), Službeni list SFR Jugoslavije, br. 29/78, 39/85, 45/89-Odluka Ustavnog suda Jugoslavije, i br. 57/89; Službeni list FR Jugoslavije, br. 31/93, 22/99, 23/99, 35/99, 44/99; i Službeni list Srbije i Crne Gore, br. 1/2003- Ustavna povelja Državne zajednice Srbija i Crna Gora; Retrieved 19 November 2018 from https://www.mpravde.gov.rs/files/ The\%20Law\%20of\%20Contract\%20and\%20Torts_180411.pdf

Građanski zakonik Republike Srbije-Radni tekst (The Civil Code of the Republic of Serbia-Working Document), Vlada Republike Srbije, Komisija za izradu Građanskog zakonika, Beograd 29.maj 2015; Retrieved 02 August 2018 from https://www.mpravde.gov.rs/files/NACRT.pdf

Privredna komora Srbije, Franšizno poslovanje (The Serbian Chamber of Commerce: Franchise Business), Accesseed 05 August 2018 at http://www. pks.rs/MSaradnja. $a s p x ? i d=679 \& p=0 \&$ 


\title{
Др Страхиња Д. Миљковић,
}

Доцент,

Правни факултет Универзитета у Приштини,

са седиштем у Косовској Митровици

\section{ПРЕСТАНАК УГОВОРА О ФРАНШИЗИНГУ У СВЕТЛУ ПОЗИТИВНОГ ЗАКОНОДАВСТВА РЕПУБЛИКЕ СРБИЈЕ}

\begin{abstract}
Апстракт
Потреба капитала за освајањем нових тржишта кроз минимална инвестициона може се постићи путем франшизинга као специфичног инвестиционог метода уговорног пословања. Коришћење метода успешног пословања, смањени инвестициони ризици и аутономија у пословању су један од кључних разлога за приступање франшизинг мрежи од стране потенцијалног примаоца франшизе. У складу са одсуством законске регулативе у Републици Србији, на уговор о франшизингу примењују се одредбе Закона о облигационим односима. Одредбе Закона о облигационим односима којима се регулише престанак уговора о трговинском заступништву и уговора о лищенци могу аналогно применити на престанак уговора о франшизингу.
\end{abstract}

Кључне речи: уговор о франшизингу, франшиза, престанак уговора, редован престанак, отказ, Закон о облигационим односима. 